To determine, in each particular case, the ephemeral rôle of the tissue considered.

Anatomy and Zoology.-The Savigny prize (I50o francs), for the assistance of young travelling zoologists, not in receipt of Government assistance, and who specially occupy themselves with the invertebrate animals of Egypt and Syria; the Thore prize (200 francs), for the best work on the habits and anatomy of one species of European insect.

Medicine and Surgery.-A Montyon prize (2500 francs and mentions of 1500 francs), for a discovery useful in medicine; the Barbier prize (2000 francs), for a discovery of value to medical, surgical or pharmaceutical science, or botany in relation to medicine; the Bréant prize (100,000 francs), for the discovery of a cure for Asiatic cholera or the definite cause of this disease. If the prize is not awarded, the interest will be given for researches bearing on cholera or other epidemic disease. The Godard prize (rooo francs), for the best memoir on the anatomy, physiology, and pathology of the urinogenitary organs; the Baron Larrey prize (750 francs), for a work treating of military medicine, surgery, or hygiene; the Bellion prize (I 400 francs); the Mège prize (I0,000 francs); the Dusgate prize (2500 francs), for the best memoir on the diagnostic signs of death and on the best means of preventing premature burial.

Physiology. - A Montyon prize (750 francs), for a work on experimental physiology; the Philipeaux prize (900 francs), for the same; the Lallemand prize (I80o francs), for works relating to the nervous system; the MartinDamourette prize ( 1400 francs), for a work on therapeutical physiology; the Pourat prize (I000 francs), for a memoir on the action exercised by the X-rays and the radium rays on the development and nutrition of living cells.

Statistics.-A Montyon prize (Iooo francs, and a mention of 500 francs), for the most useful work dealing with statistics.

History of Science.-The Binoux prize (2000 francs).

General Prizes.-These include the Arago, Lavoisier, and Berthelot medals; the Gegner prize (3800 francs); the Lannelongue prize (2000 francs); the Trémont prize (I 100 francs); the Wilde prizes (one of 4000 francs and two of 2000 francs), for discoveries in astronomy, physics, chemistry, mineralogy, geology, or experimental mechanics; the Lonchampt prize (400o francs); the Saintour prize (3000 francs); the Victor Raulin prize (I 500 francs), for a work on the meteorology and physics of the globe; the prize founded by Mme. la Marquise de Laplace; the Félix Rivot prize (2500 francs); the Leconte prize (50,000 francs), for important discoveries in mathematics, physics, chemistry, natural history, or medicine; the Houllevigue prize 5000 francs); the Caméré prize (4000 francs); the Jérome Ponti prize (3500 francs).

Of these, the Pierre Guzman, Lalande, Tchihatchef, Delesse, Desmazières, and Leconte prizes are expressly stated to be offered with preference of nationality.

\section{CHEMICAL RESEARCH AT THE UNIVERSITY OF MANCHESTER.}

THE chemical schools at the University of Manchester, probably already the largest in the kingdom, are being enlarged by the addition of a new block of buildings at a cost of about 20,000 . Already considerable progress has been made with the building operations, and it is hoped that the new block will be ready for opening in the early autumn of 1909 . The chief addition will be a new large laboratory having accommodation for forty students, and fifteen smaller research laboratories.

The following description of the objects of the new buildings is taken from a recent interview with Prof. W. H. Perkin, published in the Manchester Guardian. He considers that the loss of the coal-tar industry to this country was due, not only to the manufacturers not realising the importance of employing chemists and carrying out research work, but also to the universities, which were very greatly to blame. Organic chemistry was hardly taught at our universities, and such laboratories as they possessed were poor and ill-equipped. As a consequence, if manufacturers did require chemists they could not obtain them.
It was in 1874 that the original coal-tar colour works at Greenford Green, near Harrow, were sold. The reason for giving up the works was partly owing to the natura dislike for an industrial career of the late Sir William Perkin and his desire to devote himself entirely to research chemistry; but it was also because he recognised that the works could not be satisfactorily carried on and be able to compete successfully with the rising industry in Germany unless he took into the works a large number of research chemists, as the Germans had done. But although inquiries were made at many of the British universities in the hope of finding young men trained in methods of organic chemistry, such men were not forthcoming.

The older universities at that time scarcely recognised organic chemistry; it is doubtful whether they thoroughly appreciated chemistry at all. The newer universities, which at present are doing such good work and of which we are justly proud, had not come into existence. Prof. Perkin said he was strongly of the opinion that the manufacturer of organic products during $1870-1880$ was, owing to this neglect of organic chemistry by our universities, placed in a very difficult and practically impossible position.

But, in the meantime, organic chemistry had taken root in Germany, and great schools devoted to this branch of chemical science had been founded. History tells us how the German manufacturers made use of the young chemists who had been trained in these laboratories. Consequently, the works in Germany increased in size and in number, and obtained the world's trade in organic chemicals. Had our universities at this time pursued the same principle, in all probability the coal-tar colour and allied industries would not have been lost; but now this state of things has changed, and "I am convinced that failure on the part of the manufacturers to develop any industry connected with organic chemistry is no longer due to the impossibility of obtaining the services of young chemists of ability.'

The scheme which it is hoped to develop in connection with the Manchester Chemical School is laid on the lines which have been found so valuable abroad. Two lines of procedure are open to the manufacturer.

$\mathrm{He}$ may send his sons to the university, and as soon as they have passed through the honours B.Sc. course, and have thus received a thoroughly sound general training, they will be fit to engage in research work dealing with problems of a technical nature, either suggested by the university professors or by the manufacturers. Such a course, extending over two or more years, will be the best preparation for an industrial career.

Another way in which the manufacturers can be helped if they wish to solve a difficult problem or invent some new process is to place at their disposal one of the smaller research rooms. In this room his own research chemist from the works can, under the best conditions, investigate the problem, either alone or with assistance from the university staff. If he happens to have no research chemist available for the purpose, one of the university graduates can be engaged to work under the professor's superintendence.

The University will, however, not open its doors to do purely routine analysis, ordinary commercial work, or patent litigation. It lays itself out to train research chemists or help by research work, and in this direction alone.

\section{WATERS AND GLACIERS.}

UNDERGROUND waters play a considerable part in recent researches on French caves (Spelunca, tome vii., 1907-8, Nos. 47-52). M. Fournier's observations in the Jura (Nos. 47 and 50 ) are largely concerned with following out the courses of streams that are used for household purposes. He agrees with $M$. Martel that springs may be regarded with suspicion when their temperature varies by even $\mathrm{I}^{\circ} \mathrm{C}$. from that of water in the same region which is known to come from considerable depths. A number of caves in various levels of Jurassic limestone are drawn in plan and section, and the continuity of certain streams has been proved by the use 
of fluorescein. As an example of the practical results of such researches, it may be mentioned that the village of Mouchard, on the west flank of the range, was found to be utilising an already contaminated water, which ran away out of the public fountain and reappeared as the main supply of Pagnoz, a hamlet on the Salins road. The author complains that it is hard to move local authorities; but, if Mouchard now becomes grateful, Pagnoz may be doubly so. Messrs. Albert and Alexandre Mary (No. 48) describe the artificial excavations in the chalk at Saint-Martin, Oise, and urge that the movement of water in chalk is controlled by fissures, which are in some cases fault-planes, and not by a general porosity of the rock. Where the chalk is fractured on a small scale, as in the Upper Senonian, owing to the yielding character of a particular series of beds, the water flows along the abundant and delicate crevices; where, however, there are only coarser joints, these become the prominent and effective water-ways (p. 13 ). The caverns in Oise may have been dug out by man as hiding places, but the fissures selected had previously been widened by natural waters. About the twelfth century they became used as quarries. This memoir by MM. Mary concludes with an account of the modifications that took place in certain plants removed by the authors from the outer air to the banks of one of the subterranean lakes. M. Ed. Rahir (No. 51) reports on caves in the Carboniferous Limestone of Belgium; and M. Paul Macey (No. 52) carries us away to Indo-China, and gives a spirited account of rivers that penetrate masses of limestone in the province of Cammon, of which he is Governor. His zeal for exploration is not more commendable than his regard for the religious feelings of his subjects. We wonder if all British cavehunters would have sacrificed a pig and a few fowls before descending a haunted river in a collapsible bamboo canoe. The cheerful description of two days underground on this unknown water-way should satisfy even $M$. Martel, to whom it is presented. The tunnel of the Nam Hin-Boun, 4000 metres long, is, on the other hand, used as a highway by the natives themselves when the river is low. The basin of Hang Nam-Thieng (vessel of holy water) reminds us of the miraculous stoup attached to an old church in Anglesey; it is about 15 centimetres in diameter, and re-fills itself up to a certain level after water is drawn from it: The French have again allowed the use of its water in ceremonial oaths, according to a practice that had fallen into disuse since the Siamese invasion of 1827 .

The production of valleys and deltas has been studied artificially by Mr. T. A. Jaggar, jun. ("Experiments illustrating Erosion and Sedimentation," Bull. Museum of Comp. Zoology, Harvard, vol. xlix.; 1908, p. 285). Various rock-powders are strewn over one another in layers, or slimes from a stamp-mill are deposited from water. The surface is then tilted at $20^{\circ}$ and is subjected to a water-spray, furnished by a compression apparatus and an atomiser such as barbers use. Rill-systems arise on the slime-surface after one or two hours. and illustrations of river-capture (p. 299) occur among their details.

Mr. E. F. Pittman, Government geologist of New South Wales, in his Clark memorial lecture (Geol. Survey of New South Wales, Sydney, 1908), has reviewed the very important question of the artesian water-supply Australia. He sees many reasons for opposing the view of Prof. J. W. Gregory, who has maintained that the water rises from plutonic depths under the influence of earth-pressure, and not as the result of hydrostatic flow in an artesian basin. Mr. Pittman believes that the rainfall on the exposed edges of the sandstones in the Great Dividing Range in south-eastern Queensland and in the north of New South Wales is sufficient to account for the water stored in the artesian area. He agrees with Prof. J. W. Gregory in deprecating the waste of this water that is at present tolerated. In a coloured map he indicates the enormous area of the main basin, extending from the central part of the Darling River through Queensland to Cape York.

Passing to the solid form of water, the Actes de la Société helvétique des Sciences naturelles, for the ninetieth session at Fribourg, in $190 \%$, contains much that is interesting in the study of glaciers. Prof. Mühlberg, of Aarau, reviews (p. 9r) the state of Switzerland during the
Ice age, which he properly regards as a world-wide phenomenon. He suggests (p. 94) that certain moraines in Alsace were recognised as the deposits of former glaciers so far back as the middle of the eighteenth century; but all that he really proves is that these ridges were called moraines by settlers from. Switzerland. De Saussure tells us that this term, variously spelt in his day, originated in Savoy, where it was applied to any steeply sloping piece of hillside. Jean-Pierre Perraudin, the chamois-hunter of the Val de Bagne, seems still to hold his own as the first to realise that the Swiss glaciers were formerly of far greater extent. Prof. Jean. Brunhes, curiously enough, emphasises the observations of Perraudin on glacial stria in a paper on "Le Problème de l'É:osion et du Surcreusement glaciaire" (ibid., p. I55). Prof. Brunhes seeks to show that there is little real distinction between geographical features that are claimed as of glacial origin and those produced by rivers. A main stream, he urges (p. I64), will cut down its bed below those of its tributaries, though the difference of level will diminish as the river-system grows older. We hardly follow him when he sees the U-form, commonly held to result from glacial action, repeated in the floor of the Colorado canyon; but he points out very usefully that the streams under the ice near each margin of a glacier often produce two parallel surcreusements of the valley-floor, with a glaciated rockridge between them (p. 166). This common phenomenon, which he illustrates by photographs, is very different from the trough-like form which the advocates of glacial erosion attribute to rapidly moving ice. While Prof. Brunhes believes that the subglacial water is the main agent in lowering the valley-floor, he shows how abrasion by ice may ultimately remove the central rib which characterises earlier stages of erosion. The two agents must be regarded as working together, and not in succession to one another, if we would correctly appreciate valley-forms.

The twelfth report of the Commission internationale ces Glaciers, in which variations of glaciers are recorded from all parts of the world, appears in the second volume of the Anmales de Glaciologie (1908), pp. 161-198. An abstract of this, by $M$. Forel, has been already reviewed in Nature by Prof. Bonney (vol. Ixxviii., p. 574). In Naturen, published in Bergen, vol. xxxil. (I908), p. II 8 , Herr J. Rekstad records both recessions and advances among Norwegian glaciers between 1900 and 1907. The cold summers of 1902,1903 , and 1904 are responsible for many advances and thickenings in the lower parts of the ice-streams, and the full results of that of 1907 have yet to manifest themselves.

Mr. H. H. Hayden's " Notes on Certain Glaciers in North-west Kashmir" (Records, Geol. Survey of India vol. xxxv., r907, part iii., p. 127) records the establish ment of stations bv which rates of movement mav be determined. The Yengutsa Glacier has advanced about two miles since rgoz, and has overwhelmed mills that then risted in a stream-cut stretching from its foot. The Hassanabad Glacier, on the evidence of competent native officials, advanced "about three years ago" six miles or more in two and a half months. It seems liable to extraordinarily rapid fluctuations, and is now said to be stationary. Clearly, accurate records will be of special interest in this case. Other glaciers in Kashmir show "steady secular retreat." One would like to learn if the local advances can be traced to exceptional snowfalls, or even to earthquakes, as in recent instances in Alaska. The great attraction of Mr. Hayden's paper lies in the superb photographic plates by which it is illustrated. That of the Hassanabad Glacier lying in its ravine is especially successful.

In the Bulletin of the American Geographical Society, vol. xxxix., March, r907, Messrs. Tarr and Martin comment on Prof. Russell's conclusion that the Hubbard Glacier of Alaska has receded five miles since r794. From their personal experiences in 1906, they hold that Malaspina's remarks on ice as an obstacle in the bay referred only to floating ice, and this seems confirmed by the evidence of the vegetation and by the occurrence of wave-cut shore-lines in the region which, according to Russell, would have been covered a century ago by glacierice.

Perhaps we may include in this notice Messrs. 
Sheppard and Stather's account of a fine section made in England by the North-Eastern Railway Company in the glacial gravels of Holderness (Proc. Yorkshire Geol. Soc., vol. xvi., 1907, p. 171). A few molluscan species from the drifts are added by the authors to those already known; but the main interest lies in the bones of mammoth, bison, horse, walrus, \&c., which are believed to have been pushed up inland from the beach by the encroaching ice-front.

G. A. J. C.

\section{THE TRANSVAAL AND INDIAN DEPART- MENTS OF AGRICULTURE.'}

(1) THE annual report of the Transvaal Department of Agriculture recently to hand gives a vast amount of interesting information about the department and the work it is doing among the agricultural community of the Transvaal. The agricultural conditions at the time of its formation were about as bad as it was possible for them to be. Animal diseases were rife, and besides the ordinary diseases of the country a number of new ones had been introduced during the war. The harvests had been neglected, consequently there was a shortage of seed corn; indeed, some varieties were almost, if not quite, lost. The land was in the bad state into which it rapidly falls when neglected, and out of which it can only be brought by dint of much skilful labour. Only a strong agricultural department could have met the necessities of the case; a weak one might easily have done a great amount of harm.

The occasion was one when the ordinary British instinct would have been to send out a number of "practical" men to devise "practical" measures for coping with the various problems. Fortunately, the British instinct did not prevail; the various heads of departments were men of scientific training, who began by making a study on scientific lines of the conditions with which they had to deal. As might have been expected, the result has been eminently satisfactory. The Public Service Commission declared itself unable to suggest any alterations or improvements in the general plan, and even the commissioner who was appointed to go into the detailed workings only made a few minor alterations in the clerical staff; amid much retrenchment in other directions this department has been left practically untouched. To the director, Mr. F. B. Smith, belongs the credit of having boldly conceived the plan and vigorously executed it; to the scientific staff belongs the credit of having risen to the occasion, and, in the words of one of the Transvaal newspapers, "triumphantly vindicated the practical value of research work."

It is just this "triumphant" vindication that gives the department a world-wide, and not merely a local, importance. No one can read the report and the other publications of the department without being impressed with "the practical value of research work." The investigations of Dr. A. Theiler, of the veterinary bacteriological laboratory, afford admirable cases in point. A number of the animal diseases with which the country abounds have been studied; in many cases the particular organisms causing the diseases have been identified, and the method by which they are conveyed from animal to animal discovered. The knowledge thus gained has made it possible to devise means for controlling the disease. This year's experiments have dealt more particularly with Piroplasma mutans, an organism that had previously been confounded with the Piroplasme begeminum producing a South African redwater, and it shown that the disease, sometimes contracted even after inoculation, and thought to be ordinary redwater, is really brought on by the newly discovered Piroplasma. " sickness " and "biliary fever" in horses have also been investigated, and inoculation against the latter disease can now be satisfactorily performed, as also can inoculation

1 (r) Annual Report of the Transvaal Department of Agriculture, roo6-7 (received September, rgo8). The Transvaal Agricultural fournal, vol. vi., rgo8.

(2) Report of the Imperial Department of Agriculture for the Years I905-6 and 1906-7: (Received October, r908.)

The Agricultural Journal of India, vol. iii., 1908

Memoirs of the Department of Agriculture in India.

NO. 2043, VOL. 79] against "blue tongue" in sheep. Great as is the immediate value of this kind of work, its future value is even greater; the Transvaal is essentially a stock-producing country, but stock cannot be raised in number until the diseases are more under control.

In the botanical section Mr. Burtt-Davy has been examining the native flora and more closely studying promising plants; the habits of troublesome weeds have also been investigated, and methods devised for their eradication. Satisfactory progress is also reported by the plant pathologist, Mr. Pole Evans. During the year 300 different kinds of fungi and plant diseases were dealt with, a large proportion of the latter being previously un. described. Attention this year has been largely directed to bitter-pit in apples, a disease causing enormous loss to apple growers, on which a full report is promised at a later stage. Rusts affecting cereals and other economic Gramineæ have also been studied, and the "South African locust fungus" has been shown in its true light. Locusts are sometimes fatally attacked by a fungus, Empusa Grylli, Fres., and the Cape and Natal Governments cultivated and distributed what they thought was the fungus with the view of exterminating locusts. Mr. Pole Evans, however, found that the cultures were not Empusa at all ; in fact, Empusa is a pure parasite which cannot be cultivated on artificial media, and is therefore of no practical value as an exterminating agent. On following the matter up, he found that Empusa had been the starting point in the Cape cultures, but the harmless Mucor exitiosus had appeared, and had been propagated and widely distributed under the impression that it was a destructive organism!

The working of the other sections-entomological, forestry, chemical, \&c.-appears to be on equally sound lines, while the experimental farms have appealed strongly to the Boer farmer. At the Rand Agricultural Show the department's farms were very successful, both in the competitions and in their other exhibits.

Altogether the working of the department reflects great credit on all concerned, and affords abundant illustration of what science can do for agriculture.

(2) The history of the foundation of Pusa, the Indian agricultural experiment station, is too well known to need repetition here. The recently issued report shows the results already obtained, and indicates the broad lines on which work is to proceed; progress has been steady, and the character of the work promises well for the future of Indian agriculture.

Naturally we can only look for preliminary results at the present stage. Work at Pusa has hitherto gone on under a certain amount of difficulty. The buildings have not long been completed. The staff have had very little assistance; experienced natives to supervise field experiments and to give other help were not at first obtainable and have had to be trained up. Some of the experimental plots were ruined by sudden floods, to which the estate is liable, owing to heavy, continuous rain. All this makes research work difficult, and the staff deserve high credit for having accomplished so much in these rather unfavourable circumstances.

Considerable attention has been devoted to the study of crops suited to Indian conditions-cotton, sugar-cane, jute, flax, tobacco, wheat, \&c. The possibility of extending cotton cultivation in India is being carefully investigated, certain grants being made for the purpose by the British Cotton-growing Association; so far, the most hopeful line of development seems to be to make the best of the indigenous varieties rather than to introduce new and finer varieties. Serious attempts are also being made to strengthen the position of the indigo planter, and, in addition to the work being done by $\mathrm{Mr}$. Bergtheil, a botanist has been engaged by the Planters' Association to improve the indigo plant by selection and breeding. The Indian wheats are being collected by Mr. Howard, and type-specimens separated from the mixed crop usually grown; these are described in a monograph, which will be awaited with considerable interest. Similar work on the native barleys and tobaccos is in hand. In all these cases cross-breeding, selection, and distribution of varieties true to type will follow.

The chemical department has, up to the present. been 